\title{
PENGEMBANGAN DAN PENERAPAN APLIKASI \\ INDONESIA INTEGRATED ROAD MANAGEMENT SYSTEM PADA DIREKTORAT JENDERAL BINA MARGA
}

\author{
Hartanto \\ Sekolah Tinggi Manajemen Informatika dan Komputer LIKMI \\ Jl. Ir. H. Juanda 96 Bandung 40132 \\ hartanto_27@yahoo.co.id
}

\begin{abstract}
ABSTRAK
Penelitian ini bertujuan untuk menjelaskan pengembangan dan penerapan aplikasi Indonesia Integrated Road Management System (IRMS) di Direktorat Jenderal Bina Marga yang mendukung manajemen aset (terdiri dari jalan, jembatan, dan keselamatan pengguna) di Indonesia yang berbasis web dengan sistem pengelolaan basis data relasional (RDBMS) dan menyimpan database aplikasi, database spasial dengan memanfaatkan Sistem Informasi Geografis berbasis server untuk menyebarkan data spasial. Penelitian ini menjelaskan tahapan pengembangan aplikasi IRMS serta fitur dan modul-modul yang terdapat didalamnya.

Aplikasi IRMS juga menyimpan semua data secara terpusat (aset jalan, jembatan, kondisi, riwayat pemeliharaan, material, kepadatan lalu lintas, data tilang, dan korban kecelakaan) di Indonesia sehingga dapat melakukan analisa untuk menentukan perlakuan tingkat perbaikan jalan, memprediksi kondisi jembatan, dan mengidentifikasi lokasi rawan kecelakaan, menyusun rencana dan anggaran serta membuat rencana pencegahan sebelum terjadinya kerusakan yang parah.
\end{abstract}

Kata kunci : IRMS, sistem informasi geografis, jaringan jalan, jembatan, keselamatan pengguna

\section{PENDAHULUAN}

Penelitian ini berjudul pengembangan dan penerapan aplikasi Indonesia Integrated Road Management System (IRMS) di Direktorat Jenderal Bina Marga bermaksud untuk menjelaskan tahapan pengembangan aplikasi IRMS yang merupakan suatu aplikasi manajemen aset (terdiri dari jalan, jembatan, dan keselamatan pengguna) berbasis web dengan sistem pengelolaan basis data relasional (RDBMS) yang menyimpan database aplikasi dan database spasial dengan memanfaatkan Sistem Informasi Geografis (SIG) berbasis server untuk menyebarkan data spasial.

Dengan adanya penerapan aplikasi IRMS diharapkan tersedianya pangkalan data jaringan Jalan dan jembatan yang tersusun secara sistematis dan teratur, sehingga dapat digunakan dalam program perencanaan, penyusunan anggaran, dan penanganan jalan, dan jembatan serta didukung dengan data keselamatan pengguna yang dapat membantu dalam perancangan jalan dan jembatan. 


\section{TINJAUAN PUSTAKA}

Aset yang dikelola di Direktorat Jenderal Bina Marga meliputi Jalan dan Jembatan. Berdasarkan Peraturan Menteri Pekerjaan Umum Nomor : 19/PRT/M/2011, menjelaskan bahwa Jalan adalah prasarana transportasi darat yang meliputi segala bagian jalan, termasuk bangunan pelengkap dan perlengkapannya yang diperuntukkan bagi lalu lintas, yang berada pada permukaan tanah, di atas permukaan tanah, di bawah permukaan tanah dan/atau air, serta di atas permukaan air, kecuali jalan kereta api, jalan lori, dan jalan kabel. Jembatan adalah jalan yang terletak di atas permukaan air dan/atau di atas permukaan tanah. Sistem Jaringan Jalan adalah satu kesatuan ruas jalan yang saling menghubungkan dan mengikat pusat-pusat pertumbuhan dengan wilayah yang berada dalam pengaruh pelayanannya dalam satu hubungan hirarki. Sistem Jaringan Jalan disusun dengan mengacu pada rencana tata ruang wilayah dan dengan memperhatikan keterhubungan antar kawasan dan/atau dalam kawasan perkotaan, dan kawasan pedesaan. Sistem Jaringan Jalan dapat dikelompokkan menurut pelayanan jasa distribusinya (fungsi) dan menurut wewenang pembinaannya (penanganan) [1].

Pada aplikasi IRMS juga terdapat pengelolaan basis data oleh suatu perangkat lunak yang spesifik. Perangkat lunak ini yang disebut DBMS (Database Management System). Perangkat lunak yang akan menentukan bagaimana data diorganisasi, disimpan, diubah dan diambil kembali. Perangkat lunak ini juga menerapkan mekanisme pengamanan data, pemakaian data bersama dari banyak pengguna, keakuratan/konsistensi data. Kebanyakan DBMS bekerja dengan metode relasional sehingga sering disebut RDBMS (Relational Database Management System). Contoh RDBMS adalah Oracle, MySQL, PostgreSQL. Aplikasi IRMS juga menggunakan Sistem Informasi Geografis untuk pelaporan berjenis peta [2].

Sistem Informasi Geografis adalah suatu sistem perangkat yang dapat melakukan pengumpulan, penyimpanan, pengambilan kembali, pengubahan (transformasi), dan penayangan (visualisasi) dari data-data keruangan (spasial) untuk kebutuhan-kebutuhan tertentu. Sistem Informasi Geografis (SIG) terdiri dari 4 subsistem pokok, yaitu subsistem masukan (data input), penyimpanan (data management), pengolahan dan pengkajian (data manipulation and analysis) serta penyajian (data output).

a. Subsistem Masukan.

Fungsi dari subsistem ini adalah mengumpulkan dan mempersiapkan data spasial dan atribut dari berbagai sumber. Selain itu, subsistem ini bertanggung jawab dalam melakukan konversi atau melakukan transformasi formal. Data-data asli ke dalam format yang dapat digunakan oleh SIG.

b. Subsistem Penyimpanan.

Fungsi dari subsistem ini adalah mengorganisasikan data, baik data spasial maupun data atribut ke dalam basis data (bank data). Penyimpanan dengan cara demikian mempermudah dalam pemanggilan, pengeditan dan pembaharuan data.

c. Subsistem Pengolahan dan Pengkajian.

Fungsi dari subsistem ini adalah menentukan informasi-informasi yang dapat dihasilkan oleh SIG. Selain itu, subsistem ini juga melakukan pengolahan dan pemodelan data untuk menghasilkan informasi yang diharapkan.

d. Subsistem Penyajian.

Fungsi dari subsistem ini adalah menampilkan data dan hasil dari pengolahannya, baik sebagian maupun seluruhnya. Data dan hasil pengolahannya tersebut ditampilkan antara lain dalam bentuk tabel, grafik, dan peta (khususnya digital) [3]. 


\section{TAHAPAN PENGEMBANGAN IRMS}

Pada bagian ini menjelaskan Tahapan Pengembangan Aplikasi IRMS yang terdiri dari 2 tahap sebagai berikut :

\section{Tahap I :}

a. Pembuatan Geodatabase dan skema geodatabase jalan, jembatan.

b. Survei dan Pengumpulan data Jalan dan Jembatan.

\section{Tahap II :}

a. Pembenahan data tabular dan spasial referensi, inventaris, dan survei.

b. Meng-import data jalan, jembatan, dan kecelakaan.

c. Meng-input model, decision tree, treatment catalog, user management.

d. Menguji skenario hasil konfigurasi dan perbaikan.

e. Meng-import semua data jalan, jembatan, dan kecelakaan.

f. Mengintegrasikan dengan aplikasi SIPDJN dan GIS untuk update data.

g. Melakukan transfer knowledge.

h. Melakukan pemeliharaan sistem.

\section{HASIL DAN PEMBAHASAN}

Berdasarkan aplikasi IRMS yang telah dikembangkan, maka aplikasi ini memiliki 4 modul utama, yaitu:
a. Analis Portofolio/Trade-off Analysis.
b. Manajemen Aset Perkerasan Jalan.
c. Manajemen Aset Jembatan.
d. Manajemen Keselamatan.

\section{Modul-Modul IRMS V.3}

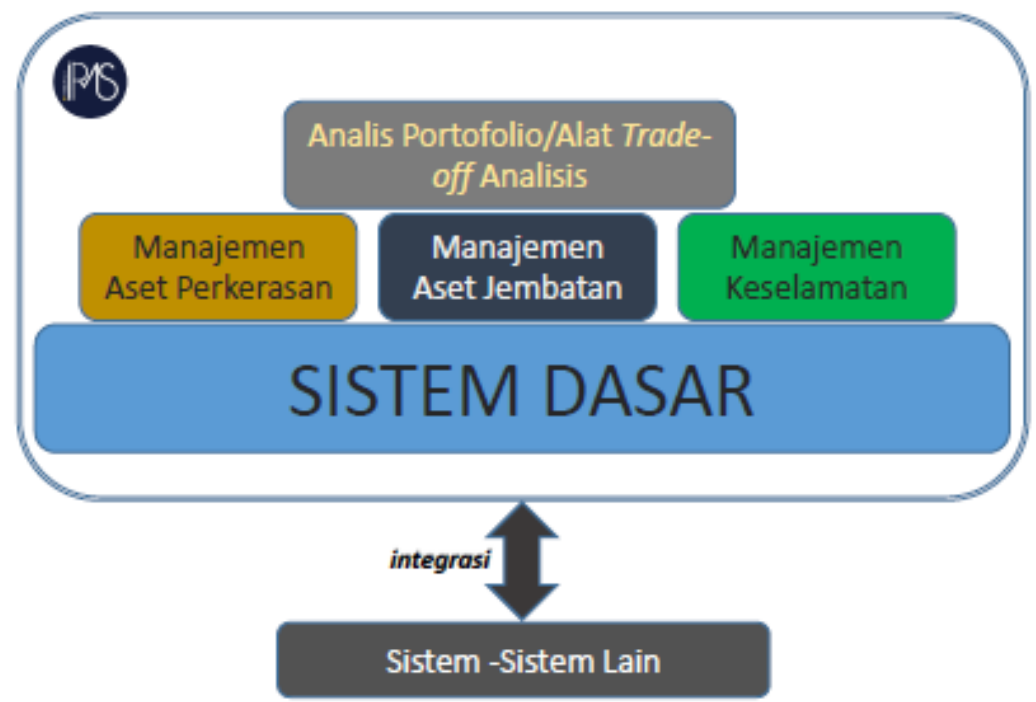

Gambar 1

Modul IRMS Versi 3

Untuk Modul Manajemen Aset Perkerasan Jalan berisikan menu Data Utama (Inventaris Jalan, Kondisi, dan lalu lintas), Menu Jenis Penanganan (Pemeliharaan Rutin, 
Preventif, Rehabilitasi Minor, Rehabilitasi Mayor, Rekonstruksi dan Pelebaran ke Standar), Menu Deterioration Rate, Menu Benefit dan Menu Skenario (lingkup, metoda, contoh objectives, constraints). Laporan yang dihasilkan dapat ditampilkan dalam bentuk Peta dan dalam bentuk grafik.

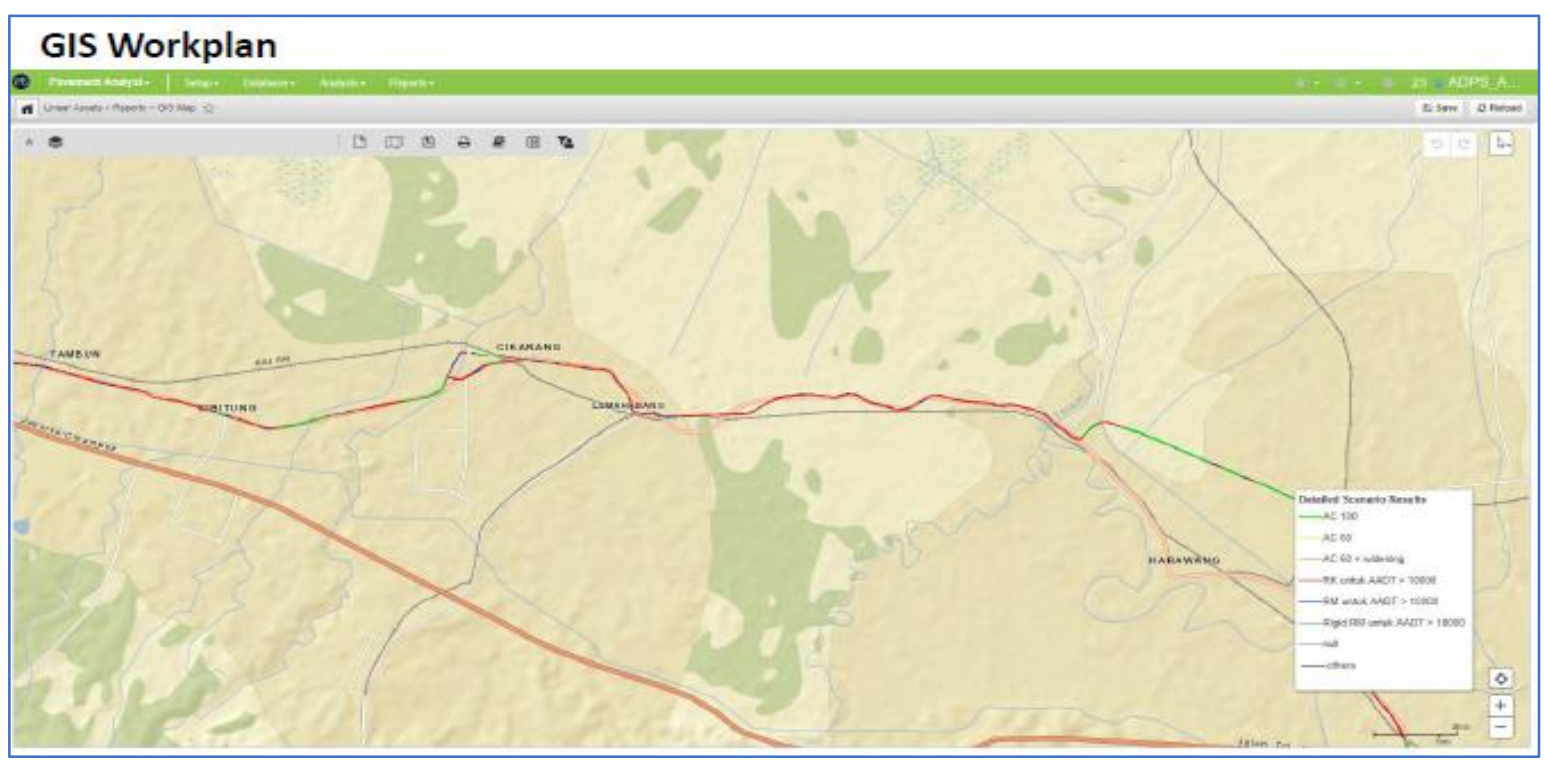

Gambar 2

Laporan dalam bentuk peta

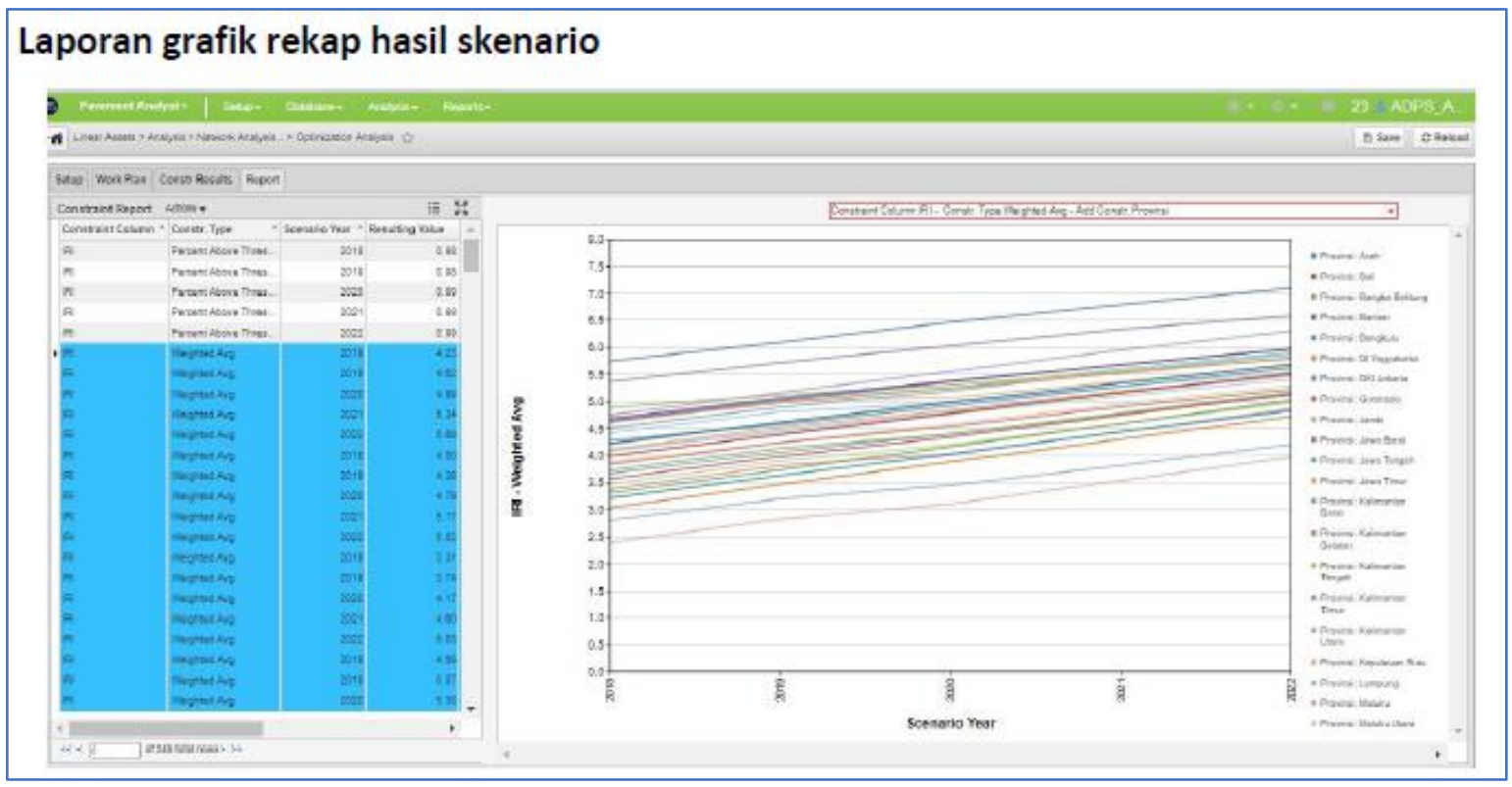

Gambar 3

Laporan dalam bentuk grafik

Untuk Modul Manajemen Aset Jembatan berisikan menu Data Utama (Inventaris Jembatan, Nilai Kondisi Jembatan), Menu Jenis Penanganan (Pemeliharaan Rutin, Rehabilitasi, Berkala, Penggantian dan Pelebaran/Penggantian/Duplikasi Jembatan Beton), Menu Deterioration Rate, Menu Benefit dan Menu Skenario (lingkup, metoda, contoh 
objectives, constraints). Laporan yang dihasilkan dapat ditampilkan dalam bentuk Peta dan dalam bentuk grafik.

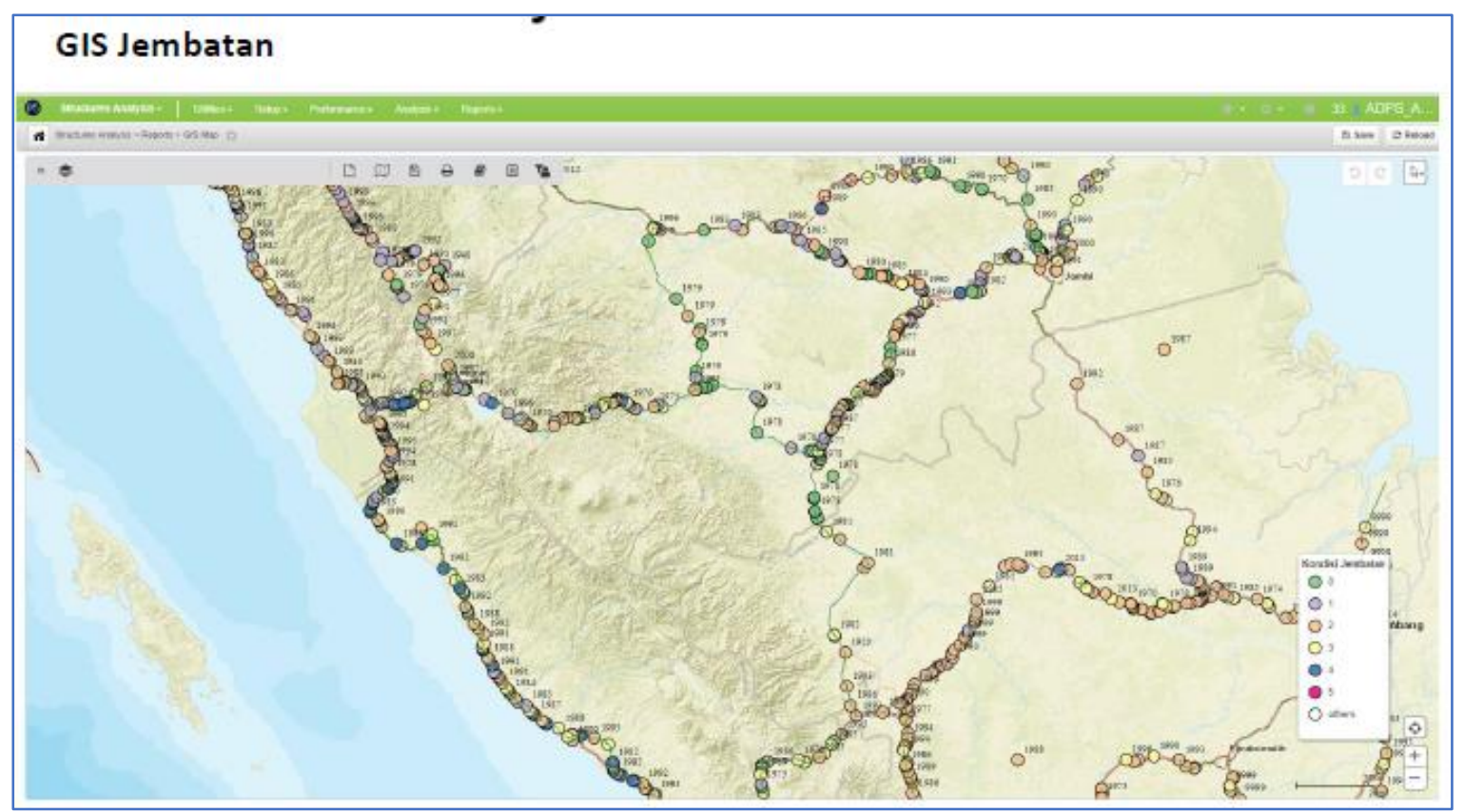

Gambar 4

Laporan dalam bentuk peta

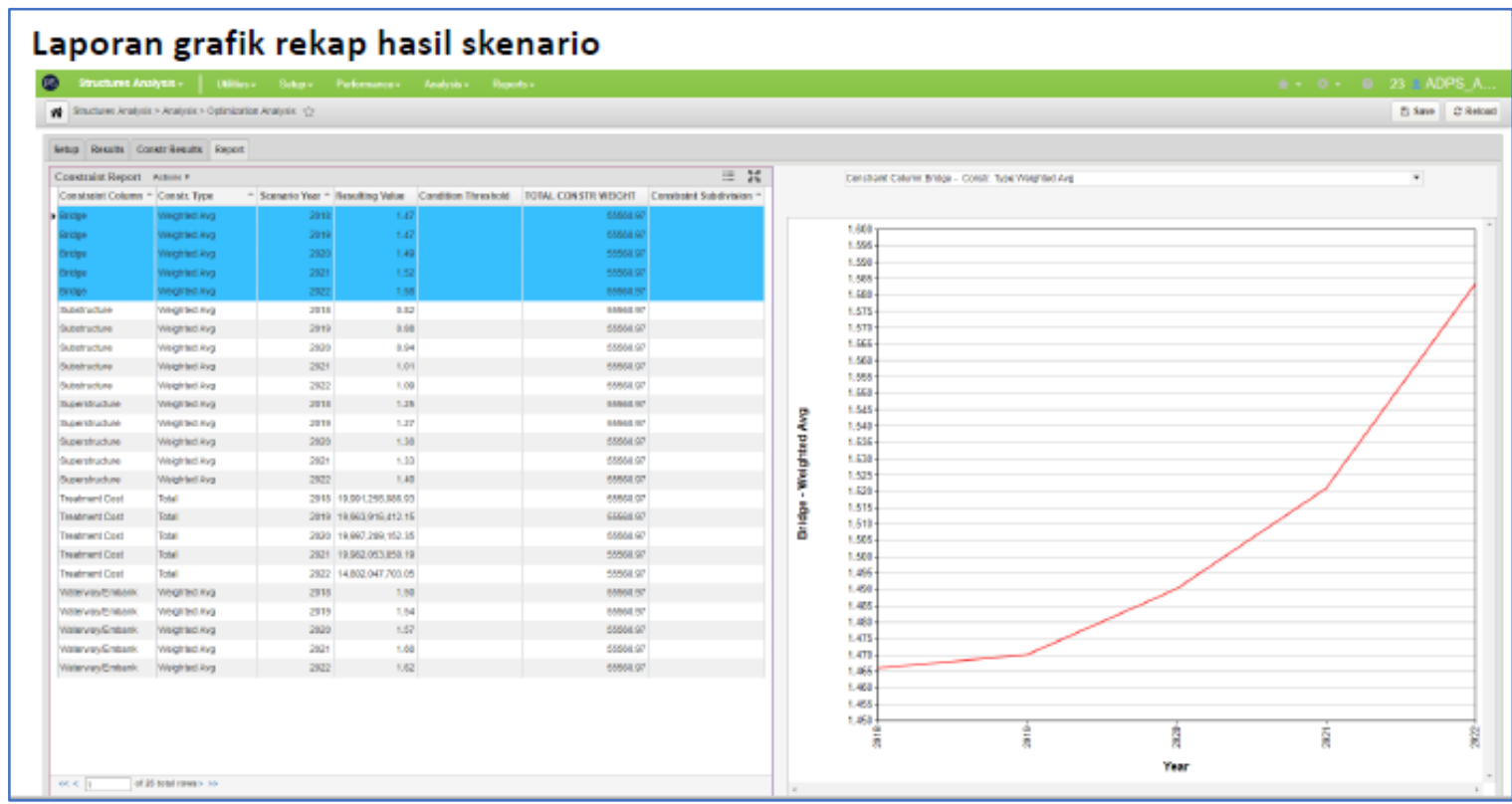

Gambar 5

Laporan dalam bentuk grafik

Untuk Modul Manajemen Keselamatan berisikan menu Data Utama (Angka Kecelakaan dan Fatalitas dari Kepolisian), Menu Jenis Penanganan (mengikuti jenis penanganan yang ada pada IRAP), Menu Crash Modification Factor (CMF), Menu Benefit (Probabilitas pengurangan jumlah korban kecelakaan di black spot/hot spot). Laporan yang dihasilkan dapat ditampilkan dalam bentuk Peta dan diagnosis blackspot/hotspot. 


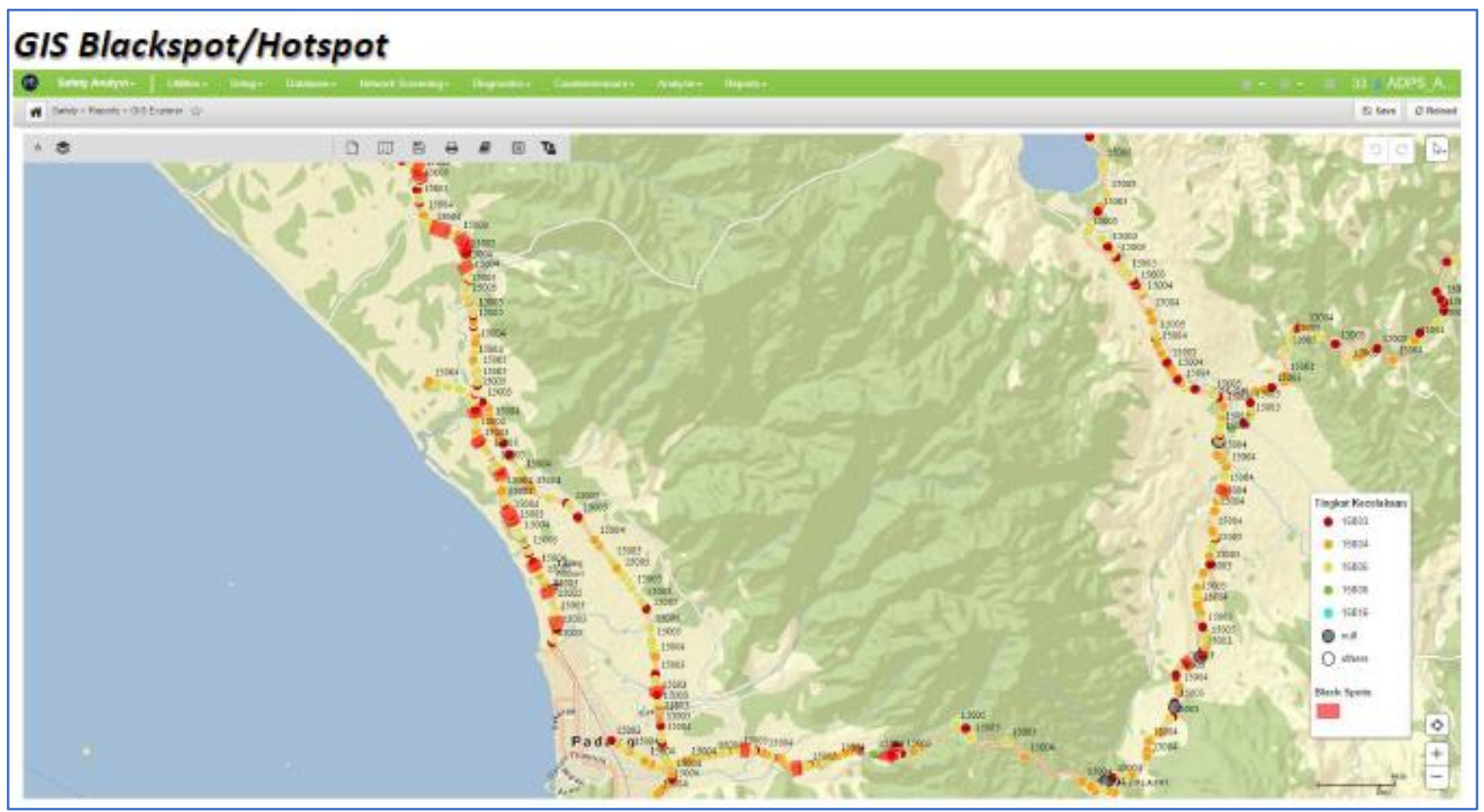

Gambar 6

Laporan dalam bentuk peta

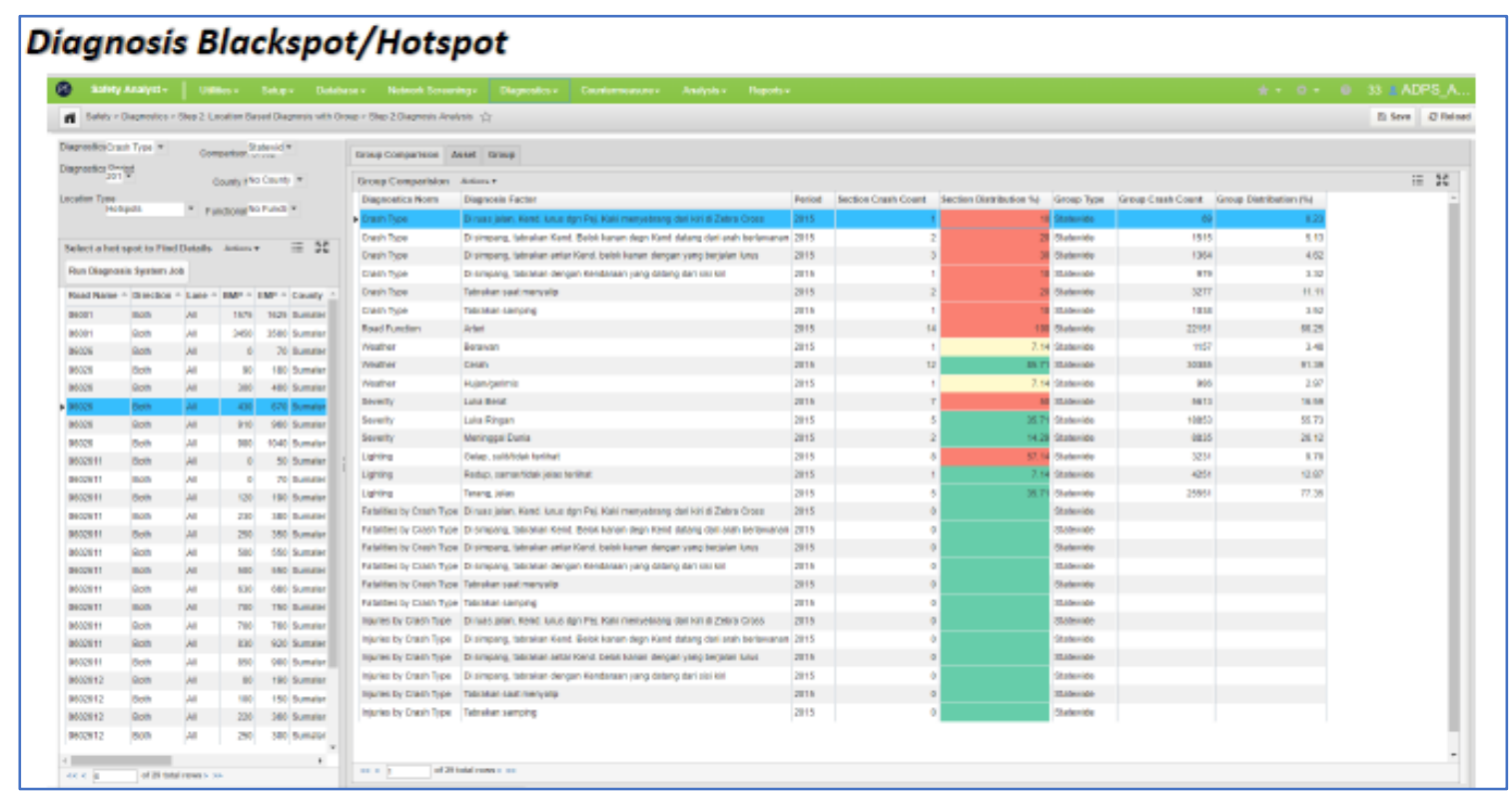

Gambar 7

Diagnosis black spot/hot spot

Pada aplikasi ini juga diterapkan mekanisme pengamanan data, pemakaian data bersama dari banyak pengguna, mendukung keakuratan/konsistensi data. Sebagian data yang dikelola oleh Aplikasi IRMS adalah data spasial. Data spasial adalah data yang memiliki referensi ruang kebumian (georeference) di mana berbagai data atribut terletak dalam berbagai unit spasial. Format data spasial dapat berupa vektor (polygon, garis, titik) maupun raster. Data spasial disimpan dan dikelola dalam Geodatabase. Geodatabase ini 
akan menyimpan semua data yang berkaitan dengan jalan, jembatan, lereng yang berbasis geospasial. Data yang disimpan merupakan data hasil survey yang sudah valid.

\section{KESIMPULAN}

Adanya penerapan aplikasi IRMS dapat membantu pimpinan di Direktorat Jenderal Bina Marga dalam penyusunan program perencanaan, anggaran, serta pembangunan, pemeliharaan jalan, dan jembatan serta didukung dengan data keselamatan pengguna yang dapat membantu dalam perancangan jalan dan jembatan. Ketersediaan data yang lengkap dan akurat adalah menjadi suatu hal yang yang penting dalam aplikasi IRMS. Oleh karena itu, aplikasi IRMS ini memerlukan adanya keakuratan data sehingga kegiatan survei yang efisien dan efektif sangat diperlukan.

Untuk mengoptimalisasi pelaksanaan survei di lapangan maka diperlukan alat bantu alat GPS Tracking, dan kamera digital. Selain itu, perlu didukung dengan kegiatan penginput-an data agar aplikasi Indonesia Integrated Road Management System (IRMS) dapat dimanfaatkan secara optimal.

\section{DAFTAR PUSTAKA}

[1] Peraturan Menteri Pekerjaan Umum Nomor : 19/PRT/M/2011 Tentang Persyaratan Teknis Jalan Dan Kriteria Perencanaan Teknis Jalan.

[2] Direktorat Jenderal Bina Marga, 2014, Pavement, Bridge Managementstem and Safety Training Booklet.

[3] Prahasta, Eddy, 2002, Sistem Informasi Geografis, Penerbit Informatika Bandung 